\title{
Courts as Rhetorical Actors: A Rhetorical Analysis of Judicial Conflict Avoidance*
}

Professor Dr. Jochen von Bernstorff, LL. M.

Chair of Constitutional Law, Public International Law and Human Rights Law, Eberhard Karls University, Tübingen, Germany vonbernstorff@jura.uni-tuebingen.de

Professor Dr. Olaf Kramer

Professorship for Rhetoric and Science Communication, Eberhard Karls University, Tübingen, Germany olaf.kramer@uni-tuebingen.de

Professor Dr. Johannes Saurer, LL. M.

Chair of Public Law, Environmental Law, Infrastructure Law and Comparative Law, Eberhard Karls University, Tübingen, Germany

jobannes.saurer@uni-tuebingen.de

Professor Dr. Stefan Thomas

Chair of Private Law, Business Law, Competition and Insurance Law, Eberhard Karls University, Tübingen, Germany thomas@jura.uni-tuebingen.de

$\begin{array}{lr}\text { Abstract } & 1002\end{array}$

$\begin{array}{ll}\text { Keywords } & 1002\end{array}$

$\begin{array}{lr}\text { I. Introduction } & 1003\end{array}$

$\begin{array}{ll}\text { II. Judicial Reasoning as an Object of Rhetorical Analysis } & 1005\end{array}$

$\begin{array}{lr}\text { III. Techniques of Avoidance in Ancient Rhetoric } & 1009\end{array}$

IV. Rhetorical Techniques of Avoidance in Judicial Reasoning 1013

1. Preliminary Remarks 1013

2. Divisio 1013

$\begin{array}{ll}\text { a) Rhetorical Characteristics } & 1013\end{array}$

b) ICJ in Kosovo-Advisory Opinion 1014

3. Immutatio / Ignoratio elenchi, Fallacy of Irrelevant Conclusion 1016

a) Rhetorical Characteristics 1016

b) ECJ on Villeroy E Boch v. EU-Commission 1017

4. Constitutio translativa: Attributing Wrong Premises 1020

a) Rhetorical Characteristics 1020

b) ICJ in Marshall Islands 1021

* This Project was supported by a University of Tübingen Platform 4 Exploration Fund in the framework of the German 'Excellence Initiative'. 
5. Simulatio: Creating, But Not Materialising New Principles

a) Rhetorical Characteristics

b) US Supreme Court in Masterpiece Cakeshop v. Colorado Civil Rights Commission

6. Playing for Time / Reticentia

a) Rhetorical Characteristics 1026

b) German Federal Constitutional Court on Head Scarf Ban 1027

\section{Abstract}

The paper starts from the assumption that there is a body of case-law on the German, the European Union (EU) level, and on the international level that is characterised by strategies of judicial avoidance. Courts for various reasons sometimes avoid deciding the substantive legal issues advanced by the parties to a conflict or put before them as a legal question in advisoryproceedings. The phenomenon is multifaceted. It can be observed in different legal contexts, in different countries, and branches of the law. From this perspective judicial avoidance is an important, yet scholarly neglected, element of judicial practice. As the paper demonstrates, it can be detected and categorised by employing the analytical tools of rhetorical science. This namely involves insights resulting from rhetorical research on 'avoidance strategies' in various forms of human and organisational communication. The central hypothesis of this paper therefore is that courts can be found to employ a sophisticated toolkit of classical rhetorical practices in order to avoid in their decision a ruling on focal legal issues of a dispute. The crossjurisdictional set of rhetorical practices, which the article traces in the practice of various selected high profile courts, goes well beyond the emanations of classic Western separation of powers-doctrines of 'judicial self-restraint', 'political questions', or the 'margin of appreciation'.

\section{Keywords}

Judicial avoidance - International Court of Justice - European Court of Justice - German Federal Constitutional Court 


\section{Introduction}

In the last two decades, one of the pre-eminent assumptions in the legal literature on courts was that courts are becoming more and more activist. In international law, scholars conceptualised an ever more activist 'global community of courts'. ${ }^{1}$ In Europe, one of the most influential approaches starts from the analysis of the European legal order as a result of judicial construction and the European Court of Justice as actor of a judicial coup d'état'. ${ }^{2}$ On the national level, the scope of judicial review of the United States (US) Supreme Court over the democratic-political process has time and again been disputed for posing a 'counter-majoritarian difficulty's ${ }^{3}$ and blurring the boundary between political branches and the judiciary. Among European national courts, the German Federal Constitutional Court is the perhaps most intensively discussed example of an 'activist court'. ${ }^{4}$ And in both the human rights and the climate change field, a new focus on strategic litigation seems to corroborate the belief in activist courts as drivers of change.

However, a closer look into judicial practice seems to challenge this prevailing view as being overly simplistic: Rather than resorting to judicial activism, courts can also often be found to avoid a substantive decision on a legal issue raised in a case. Examples can, arguably, be found in the jurisprudence of various constitutional courts, the European Court of Justice, the International Court of Justice,

1 Anne-Marie Slaughter, 'A Global Community of Courts', Harv. Int'l L. J. 44 (2003), 191219.

2 Alec Stone Sweet, The Judicial Construction of Europe (Oxford: Oxford University Press 2004), 68 (drawing on ECR, Van Gend E Loos v. Netherlands, judgement of 5 February 1963, case no. 26/62, ECLI:EU:C:1963:1; ECR. Flamino Costa v. ENEL, judgement of 15 July 1964, case no. 6/64, ECLI:EU:C:1964:66, 1253 and later cases). Alec Stone Sweet, 'The Juridical Coup d' État and the Problem of Authority', GLJ 8 (2007), 915-927 (924).

3 Alexander M. Bickel, The Least Dangerous Branch (Indianapolis: Bobbs-Merrill 1962), $16 \mathrm{ff}$.; Bickel's famous approach shapes the discourse through the present, see Pamela S. Karlan, 'The Supreme Court 2011 Term - Foreword: Democracy and Disdain', Harv. L. Rev. 126 (2012), 1-71 (14) ('the book with which all subsequent discussions of judicial review engage').

4 Extensive discussion in Matthias Jestaedt, Oliver Lepsius, Christoph Möllers and Christoph Schönberger, The German Federal Constitutional Court: The Court Without Limits (Oxford: Oxford University Press 2020); drawing on Canada, New Zealand, Israel, and South Africa Ran Hirschl, Towards Juristocracy (Cambridge, Mass.: Harvard University Press 2004); on the UK Supreme Court in this context: Jo E. K. Murkens and Roger Masterman, 'The New Constitutional Role of the Judiciary' (LSE Law Policy Briefing Series (2), 2014) at <https:// ssrn.com/abstract=2482312> or <http://dx. doi.org/10.2139/ssrn.2482312> (last accessed 18 February 2019). 
and the US Supreme Court. ${ }^{5}$ In those instances, the courts, while rendering a decision, can sometimes be found to avoid a dedicated ruling on a specific substantive legal issue in dispute between the parties. Also, from the 'margin of appreciation' doctrine as endorsed by the European Court of Human Rights there has evolved, through judicial practice, a complex concept of avoidance, which is now established in the Preamble of the Convention. ${ }^{6}$ While it is not uncommon for political actors to strategically circumvent intricate problems in the public discourse and to refrain from definitive statements on dynamic queries and societal conflicts, judicial avoidance creates a certain tension with regard to expectations regarding the functional role of the judiciary within a given legal system. Legal scholars often observe a court to not have resolved a legal conflict or to have shied away from taking a specific contentious decision. In view of the aforementioned, the topic of judicial avoidance is a recurring theme in the ever more specialised fields of domestic law and international law.

For example, Cass Sunstein identified a pattern of 'judicial minimalism' in the jurisprudence of the US Supreme Court that is characterised by the avoidance of broad rulings. ${ }^{7}$ The analysis and explanations of Sunstein have been widely discussed. ${ }^{8}$ The few more general recent inroads include, on the international level, publications on the 'backlash against international courts' dealing with 'resilience techniques' and 'patterns of avoidance' in times of political conflicts with strong political actors. ${ }^{9}$ Antonios Tzanako-

5 On the issue of the ICJ avoiding to take a position on particular questions more generally Georges Abi-Saab, 'The International Court as a World Court' in: Vaughan Lowe and Malgosia Fitzmaurice (eds), Fifty Years of the International Court of Justice: Essays in Honour of Sir Robert Jennings (Cambridge: Cambridge University Press 1996), 3-16; Hersch Lauterpacht, The Development of International Law by the International Court (London: Stevens 1958); Lyndel V. Prott, 'Avoiding a Decision on the Merits in the International Court of Justice', Sydney L. Rev. 7 (1976), 433-451.

6 Andrew Legg, The Margin of Appreciation in International Human Rights Law (Oxford: Oxford University Press 2012); Josephine Asche, Die Margin of Appreciation (Berlin: Springer 2018).

7 Cass R. Sunstein, One Case at a Time: Judicial Minimalism on the Supreme Court (Cambridge: Harvard University Press 1999).

8 See, e.g. Neal Devins, 'The Democracy-Forcing Constitution', Mich. L. Rev. 97 (2001), 1971-1993; the contributions in Yasutomo Morigiwa/Hirohide Takikawa (eds), 'Judicial Minimalism - For and Against', Archiv für Rechts- und Sozialphilosophie - Beihefte 132 (2012), 7 ff.; Jack M. Balkin, 'Arguing about the Constitution', Constitutional Commentary 33 (2018), 145-260 (181, 193-194).

9 Mikael R. Madsen, Pola Cebulak and Micha Wiebusch, 'Backlash against International Courts: Explaining the Forms and Patterns of Resistance to International Courts', International Journal of Law in Context 14 (2018), 197-220, Section 3.2.; Jed Odermatt, 'Patterns of Avoidance: Political Questions before International Courts', International Journal of Law in Context 14 (2018), 221-236; on the general issue of independence and legitimacy of international courts in times of fragmentation Geir Ulfstein, 'International Courts and Judges, Independence, Interaction and Legitimacy', N. Y. U.J. Int'l L. \& Pol. 46 (2014), 849-866. 
poulos in an International Law Association (ILA) study group report refers to doctrinally established 'avoidance techniques' of domestic courts in the non-implementation of international law, such as the 'acts of state' doctrine of non-self-executing treaties. ${ }^{10}$ And Jed Odermatt in his article on patterns of avoidance differentiates between 'principled' and 'pragmatic' reasons for avoidance. He situates the problem in the context of the political questions doctrine. ${ }^{11} \mathrm{He}$ also differentiates between reasons for judicial avoidance that refer to questions of admissibility and those that relate to the merits of a case. Both authors do not attempt to develop a taxonomy of rhetorical strategies of avoidance used by courts on all levels of jurisdiction. The entrenched scholarly focus on 'political' versus 'legal' issues in judicial decision-making, that is also reflected in Odermatt's contribution, however, is problematic: It is prone to miss out on the fact that rhetorical avoidance strategies can arguably be seen as an inherent element of judicial practice; an element which cannot be explained by reference to the alleged political/ legal dichotomy nor by re-visiting established avoidance doctrines, such as the act of state doctrine.

\section{Judicial Reasoning as an Object of Rhetorical Analysis}

This paper attempts to explore the phenomenon of judicial conflict avoidance from a comparative perspective comprising legal methodology as well as classic and modern rhetorical research. Judicial avoidance is only one of numerous fields in which a turn to rhetoric and adjacent linguistic studies complementing legal methodology can generate new scholarly insights into the role of judicial decision-making.

The paper starts from the assumption that there is a body of case law in domestic, regional and international jurisdictions that is characterised by strategies of judicial avoidance. For various reasons, courts sometimes avoid deciding the substantive legal issues advanced by the parties to a conflict or put before them as a legal question in advisory proceedings. The phenomenon is multifaceted. It can be observed in different legal contexts, in different countries and branches of the law. From this perspective judicial avoidance is an important, yet scholarly neglected, element of judicial practice. As we strive to outline in the following, it can be detected and categorised by employing the analytical tools of rhetorical science. This namely involves

10 ILA Study Group, Principles on the Engagement of Domestic Courts with International Law, Preliminary Report, para 19.

11 Odermatt (n. 9), 224. 
insights resulting from rhetorical research on 'avoidance strategies' in various forms of human and organisational communication. Such analytical tools can help, beyond mere legal scrutiny, to better detect and explain judicial avoidance. The central hypothesis of this paper therefore is that courts can be found to employ a sophisticated toolkit of rhetorical practices in order to avoid a ruling on focal legal issues of a dispute. One of our, perhaps counterintuitive, findings is that courts, despite being expected by the public to be an impartial and authoritative law-applying institution, can at times be found to rely in their reasoning on rhetorical strategies that are commonly associated with the role of parties that argue in a dispute.

The cross-jurisdictional set of rhetorical practices, which we have traced in the practice of various selected high profile courts, goes well beyond the emanations of classic Western separation of powers-doctrines of 'judicial self-restraint', 'political questions', or the margin of 'appreciation'. ${ }^{12}$ As examples of rhetorically framed judicial reasoning, judicial avoidance can overlap with such patterns of constitutional or international law. By using such established doctrines, courts can invoke substantial legal arguments often based on principles of horizontal or vertical 'separation of powers' in order to justify avoiding difficult juegements.

Through recurring court practice these arguments have developed into elastic doctrines which have been further affirmed by commentaries and legal scholarship. These 'principled' reasons ${ }^{13}$ for judicial avoidance are usually well researched, and their usefulness as well as application are being vividly debated in legal scholarship.

By contrast, the rhetorical avoidance practices explored in this contribution can be conceived of as to cloak that the court eschewed an answer on a contentious issue. A court may employ such a rhetorical strategy in substitution for a legal conclusion that would otherwise have to be drawn from a set of facts and legal rules. Such strategies can arguably be observed in the practice of various domestic courts, the European Court of Justice (ECJ), and the International Court of Justice (ICJ), or the US Supreme Court. Judicial avoidance as a rhetorical strategy can be found within the reasoning on the merits of a case as well as in rulings on the admissibility of applications or actions. As our examples will demonstrate, the employment of avoidance strategies often indicates that courts find themselves in a situation where their duty of resolving a conflict goes along with a concomitant struggle to define their own political role in an increasingly complex institutional heterarchy of executives, parliaments, or supranational organisations.

12 On these 'principled' strategies: Odermatt (n. 9).

13 Odermatt (n. 9). 
For the sake of this paper we define judicial avoidance as a rhetorical strategy cloaking or at least distracting from the fact that a court foregoes an answer to a substantive legal question raised in a dispute. A rhetorical avoidance strategy, as opposed to mere denial of justice, in our understanding involves various established rhetorical techniques. A typical example of strategic judicial avoidance, in our understanding, is to reformulate or interpret the legal issue in a way so as to avoid taking a position on the legal issue as raised by one of the parties. Reinterpreting the question with the aim to eschew an answer is a classical avoidance strategy that in ancient rhetoric is known as immutatio: a technique of reformulating an issue by leaving out aspects of the question (detraction) and adding new aspects (adiectio). ${ }^{14}$

There are, of course, many court cases where, as a matter of procedural law or of substantive law, a court is not required or even permitted to decide. Under our definition of judicial avoidance strategies, we do not refer to cases where a claim was time barred, where an action was inadmissible due to a lack of standing, or where a legal issue raised by a party was blatantly irrelevant for the case at hand. Rather, we address cases in which the court has refrained from crafting an unambiguous legal conclusion on an issue despite this issue being relevant for the outcome of the case.

Identifying cases of judicial avoidance usually requires an analysis of the judicial context and of the history of the previous decisional practice of a court. While a court might argue, in a given case, that the law prevents a ruling on the contested issue, a strategy of judicial avoidance may, nonetheless be found if the ruling is checked against previous lines of reasoning. Rhetorical avoidance might be found if, in previous cases, the same court did not shy away from dealing with a similar question, and if it did not invoke arguments of the kind used in the case at hand to deny a claim. It goes without saying that novel jurisprudence must not be equated with rhetorical avoidance. Courts can and must reshape their own jurisprudence over time. Yet it can be indicative of a rhetorical avoidance strategy if new arguments are being relied on to deny jurisdiction if there is an insufficient explanation of why this kind of argument has not been endorsed in previous cases despite the underlying facts of the dispute being comparable on all relevant accounts.

Against this backdrop, judicial avoidance might occur when a court establishes new criteria on the admissibility of an action, or when it defines new procedural requirements which are not fulfilled in the case at hand, while in

14 Cf. Heinrich Lausberg, David E. Orton and R. Dean Anderson (eds), Handbook of Literary Rhetoric: A Foundation for Literary Study (London: Brill 1998), $\mathbb{\$} 462.4$. 
previous cases such standards were not applied, without giving an explanation for why it is in this new case that those new criteria must be observed for the first time.

The aforementioned definition of judicial avoidance holds no prejudice for the underlying motives. They can be highly diverse. It is possible that a court wants to prevent an institutional conflict, possibly in order to avoid an erosion of its own powers within a given institutional setting. Also, it may be the case that the motive behind a strategy of judicial avoidance is to prevent societal unrest or even upheaval over legislative shortcomings, and to give the lawmaker an opportunity to amend the laws. Constitutional courts as well as international courts can be put in a position to decide in situations of political and economic crisis and turmoil. As a result, specific societal expectations are projected on judges so that political pressure on them rises. In such crisis-situations, judges may avoid taking substantive decisions, the consequences of which they cannot anticipate, or aim to prevent major conflicts with powerful political or private actors. ${ }^{15}$ Despite their role as formally independent institutions, courts operate in complex political settings and may thus be afraid of losing influence, power, or status. Moreover, in the light of international and transnational lawmaking, court decisions may have an effect that goes beyond domestic institutions and reaches out to foreign constituencies.

Our paper does not intend to elaborate, let alone take an ethical judgement, on these possible motives for judicial avoidance. We merely strive to describe judicial avoidance as a legal and rhetorical phenomenon, so that further research might delve into the analysis of motives. The question of whether or not a particular court has a 'good' political, institutional, economic, or moral reason for avoiding a legal argument or conclusion, is beyond our reach. As fact of the matter, the answer usually will lie in the eyes of the beholder. Instead, this contribution will make a first attempt to identify, analyse, and categorise forms of judicial avoidance. We will proceed in three steps: We will first summarise approaches to understand avoidance strategies in ancient rhetoric and modern linguistic scholarship (III.). As a second step, we will present specific rhetorical avoidance-strategies and relate them to important court judgements (IV.). In the last section, we attempt to draw broader conclusions from our findings and contemplate on avenues for further research on judicial avoidance (V.).

15 See for current tensions in the relationship between international courts and their member states: Madsen, Cebulak and Wiebusch (n. 9), Section 3.2. 


\section{Techniques of Avoidance in Ancient Rhetoric}

Rhetoric can be described as a type of functional communication that aims at persuading someone. In this teleology of persuasion, rhetoric distinguishes itself from mere information. When rhetoric is conceived of in this broadest sense, it might come as not a surprise that it can be found in the judiciary. Courts may have a genuine interest in making their reasoning appealing and strive to be accepted by both parties and by other stakeholders such as the academia. Rhetoric can help to achieve that. A closer look into the rhetorical discipline, however, reveals that rhetorical sciences differentiate between various strategies for avoiding an argument or an answer to a question which has come up within a dispute. When an orator realises that it will be too protracted, dangerous, or even impossible to counter an argument or to answer a question, he or she might employ a rhetorical strategy in order to eventually prevail in a dispute. It is this type of rhetorical avoidance strategies on which our interest rests with respect to the judiciary.

Rhetoric has evolved as a theory and practice of strategic argumentation, especially before a court, in the fifth century BC. The rhetorical challenge in judicial cases is not only to present a strong argument in a convincing way, but, much more difficult: to turn a weak argument into a strong one ('ton bêttō logon kreittō poiein'), as Protagoras put it. ${ }^{16}$ The perspective taken in the classical rhetorical texts is clearly focused on the lawyer defending a client, or a prosecutor attacking the defendant, whereas rhetorical theory deals with the judge primarily as the addressee, or as the focus point of such strategic manoeuvrings. If we observe, along the lines of our research hypothesis, that the court itself uses such rhetorical strategies to put itself in a more favourable position or to avoid a conflict, this strikes us as remarkable. Such finding seems to challenge the traditional view of a court as a decisionmaking institution, which does not pursue own interests when resolving a conflict, and which should, therefore, not find it expedient or necessary to rely on rhetoric in its own reasoning. Where such strategic manoeuvrings ${ }^{17}$ can be found in judgements, it is thereupon called for to undertake a deeper rhetorical analysis in order to detect common argumentative patterns and linguistic devices used to avoid an argument or a conclusion on a controversial issue.

16 Aristotle, Rhetoric 1402a23-5 (=DK 80B6 b).

17 Cf. Frans H. van Eemeren, Strategic Maneuvering in Argumentative Discourse: Extending the Pragma-Dialectical Theory of Argumentation (Amsterdam: John Benjamins Publishing 2010). 
Ancient rhetoric yielded a system of genera causae, implying that there are cases in which it is easy to defend someone and to find strong arguments to back a position, and other cases in which it is difficult to produce an argument in favour of a particular position at all, such as cases which are extremely controversial and precipitate ethical conundrums. ${ }^{18}$ Where the orator faces such a case (genus turpe or genus dubium), a possible strategic manoeuvre, according to Aristotle, is to avoid drawing attention to the controversial issue and instead moving on to another topic. ${ }^{19}$ This can be achieved by the use of arguments which lie outside the case, such as attacking the reputation of the opposing lawyer by associating him with unethical conduct or other questionable involvements. As already mentioned above, there is a range of possible reasons for courts to use similar techniques of rhetorical avoidance. Judicial avoidance is not necessarily driven by a fear of public conflict or the aim to avoid complex arguments. What can be said, though, is that irrespective of the motives, judicial avoidance is an effective approach in instances where the court considers that a fully reasoned decision touching on all substantive legal questions raised by the parties would entail negative effects for its own position, for other actors, or for society at large. In order to prevent such negative implications, judicial avoidance can present itself as a loophole.

Given that courts operate under the systemic expectation that relevant substantive issues raised by the parties will be decided in a reasoned judgement in line with accepted standards of the legal craft, ${ }^{20}$ the bench can have an interest not to concede openly that it shied away from an inevitable argument or a necessary conclusion. Only under exceptional circumstances can a court be legally entitled to decline a decision on a substantive issue. This is the case when the law, as applicable in a given jurisdiction, does not provide an answer to the legal question brought before the court (lacunae). Such a constellation of non-licet, however, is rarely given, since most scholars and practitioners hold the opinion that any legal dispute can and must be decided by applying classic interpretation techniques recognised by the legal craft. ${ }^{21}$ Even the lack

18 Cf. Gualtharius Calboli, 'genera causum' in: Hubert Cancik and Helmuth Schneider (eds), Der Neue Pauly - Enzyklopädie der Antike, Bd. 5, 749-751.

19 Cf. Lausberg, Orton and Anderson (n. 14), \$S 848-851; Aristotle Topics 161 a.

20 See for these constraints from the perspective of the ECJ, Ori Martin SA $v$ Court of Justice of the European Union, judgement of 7 June 2018, case no. C-463/17 P, ECLI:EU: C:2018:411, para. 18: 'As regards the first ground of appeal, it should be noted that, so as not to neglect its role, the EU judicature must examine the various claims and pleas submitted by an applicant, as formulated in his pleadings, without modifying their nature or substance (see, to that effect, judgement of 29 June 1994, Klinke v. Court of Justice, C-298/93 P, EU:C:1994:273, paragraph 20).'

21 See the famous exchange between Hersch Lauterpacht Julius Stone on the prohibition of a non liquet in international law, Lauterpacht 1933, Stone 1954. 
of a specific provision can therefore be viewed as constituting a legal rule in that it follows from the law that the situation is accepted by the legal order without any legal remedies available to the party.

Judicial avoidance, as it is of interest in our paper, therefore presupposes that rhetorical strategies are employed in order to lead the attention of the reader of the judgement away from central topics that the court was supposed to address. Rhetorically, such argumentative moves have been discussed under the term 'aversio'22 or, to be more precise, 'aversio a materia', i. e. turning away from the matter. Aversio a materia is a technique used to move away from a difficult question and to avoid a decision that might have negative effects for the speaker. In Greek rhetoric this same strategy is known under the term 'apoplanesis'. Henry Peacham in his 1577 work 'Garden of Rhetoric' already gave a suitable description of the effects of this technique:

'Aversio is a kind of aversion or turning away, and it is when the speaker leadeth away the mind of his hearer, from the matter propounded or question in hand, which maketh much against him. ${ }^{23}$

Judicial avoidance, as described above, can therefore be viewed as a line of argumentation by which the court aims to turn away from a question that might, when addressed directly, 'make something against it', ${ }^{24}$ to use Peacham's words. Moreover, when Peacham's statement is looked at from a modern perspective, it can be perceived as to entail a description of aversion as a psychological phenomenon: From a psychological point of view, aversion means that the mind of the addressee is turned away from the topic. It is a strategy used to avoid attention being paid to critical points and to achieve that attention is rather focused on a different reality.

So far, we have established that courts might find themselves in a position in which a majority of judges consider it advantageous or preferable that a substantive legal issue raised by the parties would not be decided by the court. Moreover, we have argued that courts only in very exceptional and specific circumstances will openly refuse to draw a legal conclusion in a case that has been brought before them in an admissible procedure (non licet), and that in all other cases they act under a systemic expectation to decide the case at hand, including all relevant legal issues addressed in it. We have also stated

22 Lausberg, Orton and Anderson (n. 14), $\$ \$ \$ 848-851$.

23 Henry Peacham, The Garden of Eloquence (London: Scolar Press 1577).

24 In the context of judicial avoidance this would mean 'against' the interest of the court which is to avoid a clear ruling on the substantive issue in the given case. As to possible motives for such an interest, see above our introduction. 
that there are a set of accepted 'principled' reasons for (open) judicial avoidance, such as the separation of powers doctrine. Therefore, courts in all nonopen forms of avoidance arguably need to employ rhetorical devices to turn the reasoning of the judgement away from specific legal questions - rhetorical devices that help to cover their disinclination to answer a legal question. We can now move on to identify and differentiate between these various rhetorical avoidance strategies. Again, Aristotle, in his doctrine of argumentation, provides us with a set of expedient differentiations. For Aristotle, avoidance is a process of argumentation that does not provide a valid conclusion to an argument. In his 'Topics', Aristotle also adds an important insight into the internal dynamics of strategies of communicative avoidance, according to which avoidance usually involves an objection directed at one or more aspects of a prior communicative act. He outlines promising techniques of 'objecting' which aim at avoidance in order to reach a conclusion in an argument:

'It can be done either by demolishing the point on which the falsehood that comes about depends, or by stating an objection directed against the questioner: for often when a solution has not as a matter of fact been brought, yet the questioner is rendered thereby unable to pursue the argument any farther. Thirdly, one may object to the questions asked: for it may happen that what the questioner wants does not follow from the questions he has asked because he has asked them badly, whereas if something additional be granted the conclusion comes about. If, then, the questioner be unable to pursue his argument farther, the objection would properly be directed against the questioner; if he can do so, then it would be against his questions. The fourth and worst kind of objection is that which is directed to the time allowed for discussion: for some people bring objections of a kind which would take longer to answer than the length of the discussion in hand. ${ }^{25}$

Avoidance in Aristotelian rhetoric therefore usually implies an actively communicated objection, be it against the questioner, be it through strategically misunderstanding and reinterpreting questions or by objecting to a proposed timing. The intricate reception history of Aristotle's proposed elements of successful avoidance strategies has led to a longer list of techniques or patterns of avoidance discussed in ancient rhetoric.

25 Aristotle, Topics 161 a. 


\section{Rhetorical Techniques of Avoidance in Judicial Reasoning}

\section{Preliminary Remarks}

We have identified and selected five rhetorical techniques of avoidance discussed in ancient rhetoric with a particular relevance for the field of judicial avoidance: (2.) Partly answering a controversial issue (divisio), (3.) reinterpreting and reframing the issue (immutatio), (4.) strategically disclosing wrong premises (constitutio translativa), (5.) creating an alternative case (simulatio), (6.) delaying an answer or decision (reticentia). All these techniques are based on linguistic devices and argumentative features which will be looked at more closely in the following. We will go through these five techniques and present their main features and rationales. Moreover, we will present examples for cases in which they have been used in seminal court decisions. To illustrate the transnational significance of the approach, we draw these exemplary cases from courts on all levels of modern law: the international, the supranational, and the national: We analyse cases from the International Court of Justice, the European Court of Justice, the German Federal Constitutional Court, and the US Supreme Court.

\section{Divisio}

\section{a) Rhetorical Characteristics}

Divisio is a technique of differentiating a complex question or topic in a way so that it appears in a positive light. It creates a focus on favourable points and ignores others. Divisio is a process of isolating a specific question within a more complex question for strategic reasons. If the orator then does focus on these isolated aspects of a question and scrutinises them, he can easily avoid addressing unfavourable points without appearing reluctant or unwilling to answer. It is a classical rhetorical technique used in the inventio, ${ }^{26}$ the phase of collecting and adopting the arguments of a speech, that is typically used in biased communication of litigants.

26 Cf. Cicero, Partitiones oratoriae (54 BC, Berlin: De Gruyter, German translation, 2013); Lucia C. Montefusco, 'La funzione della 'partitio' nel discorso oratio' in: Adriano Pennacini (ed.), Studi di retorica oggi in Italia (Bologna: Pitagora Editrice 1997), 69-85. 


\section{b) ICJ in Kosovo-Advisory Opinion}

Our divisio-example stems from the jurisprudence of the International Court of Justice, the most important court in the realm of international law. ${ }^{27}$ As a 'World Court' that is dependent on the acceptance of its jurisdiction by individual states, and due to its literally 'pyrotechnic' portfolio ranging from territorial and economic disputes to questions of war and peace, the ICJ is prone to now and again avoid substantive decisions by using rhetorical avoidance strategies.

In the Kosovo-advisory opinion of the International Court of Justice, the states represented in the United Nations (UN) General Assembly in a majority decision had asked the Court to decide on whether the declaration of independence of Kosovo in 2008 was 'in accordance with' international law. ${ }^{28}$ This request for an advisory opinion of the Court was the attempt of the states supporting this resolution to clarify from a legal perspective, whether or not the Kosovo against the explicit will of the Federal Republic of Serbia and Montenegro had a right to break away from that state. The wording of the question itself of course was the result of intense political negotiations within the UN General Assembly, with one group of states insisting on a narrow formulation focusing on the declaration of independence and another group aiming at clarifying once and for all the issue of remedial secession in international law. As to the (compromise-) wording of the question, it remained ambiguous. While the focus on the declaration itself implied a narrow reading, ${ }^{29}$ the use of the formula in accordance with international law' arguably implied a broader answer, including to the contested issue of self-determination and remedial secession. The Court, however, by interpreting the question at the outset in a reductionist way, excluded the question of a 'right to secession' in international law from the substantive scope of the opinion. It isolated the arguably partial question of whether or not there was a rule in international law prohibiting declarations of independence and objected to answering the other more general part implied by the question in the following words:

27 On the evolution and legal framing of the Court's function, see Armin v. Bogdandy and Ingo Venzke, In wessen Namen? Internationale Gerichte in Zeiten globalen Regierens (Berlin: Suhrkamp Insel Verlag 2014), 156-167; On the court avoiding specific decisions: Prott (n. 5), 433.

28 ICJ, Accordance with International Law of the Unilateral Declaration of Independence in Respect of Kosovo, Advisory Opinion of 22 July 2010, ICJ Reports 2010, 403.

29 The narrow focus on the declaration itself was a concession states opposing the recognition of Kosovo as an independent state had to grant in order to obtain a majority in the GA for the advisory proceedings Ralph Wilde, 'Kosovo (Advisory Opinion) in: Anne Peters (ed.), MPEPIL (online edn, Oxford: Oxford University Press 2011, para 3. 
'It follows that the task which the Court is called upon to perform is to determine whether or not the declaration of independence was adopted in violation of international law. The Court is not required by the question it has been asked to take a position on whether international law conferred a positive entitlement on Kosovo unilaterally to declare its independence or, a fortiori, on whether international law generally confers an entitlement on entities situated within a State unilaterally to break away from it. ${ }^{30}$

$[\ldots]$

A number of participants in the present proceedings have claimed, although in almost every instance only as a secondary argument, that the population of Kosovo has the right to create an independent State either as a manifestation of a right to self-determination or pursuant to what they described as a right of "remedial secession" in the face of the situation in Kosovo. ${ }^{31}$

The Court considers that it is not necessary to resolve these questions in the present case. The General Assembly has requested the Court's opinion only on whether or not the declaration of independence is in accordance with international law. Debates regarding the extent of the right of self-determination and the existence of any right of "remedial secession", however, concern the right to separate from a State. As the Court has already noted (see paragraphs 49 to 56 above), and as almost all participants agreed, that issue is beyond the scope of the question posed by the General Assembly. To answer that question, the Court need only determine whether the declaration of independence violated either general international law or the lex specialis created by Security Council resolution 1244 (1999).' ${ }^{32}$

After having isolated the question of the legality of the declaration of independence irrespective of the question of a right to secession (self-determination) in international law, the Court reaches the conclusion that the declaration as such was not illegal. Whether or not there is a rule prohibiting or granting the right of secessionist movements to break away from a recognised state entity is not dealt with in the reasoning of the Court. As a result of the majorities' use of a divisio, the heavily contested issue of whether the Kosovo-government violated international law by leaving the Republic of Serbia and Montenegro against the explicit will of the latter, is not covered by the Court.

The dissenting judge Bruno Simma, ${ }^{33}$ though, criticised the majority of judges for their artificially isolated interpretation of the question and thus for their incomplete answer:

30 ICJ, Kosovo (n. 28), 425.

31 ICJ, Kosovo (n. 28), 438.

32 ICJ, Kosovo (n. 28), 438.

33 ICJ, Kosovo (n. 28), 478. 
'With regard to my first point, I wish to recall the wording of the General Assembly's request, which asked whether Kosovo's declaration of independence was "in accordance with international law" (Advisory Opinion, para. 1). The Opinion considers that in order to answer this request, all the Court needs to do is to assess whether there exists, under international law, a prohibitive rule, thus satisfied that the lack of a violation of international law entails being in accordance therewith (ibid., para. 56). This interpretation, however, does not sit easily with the actual wording of the request, which deliberately does not ask for the existence of either a prohibitive or permissive rule under international law. Had the General Assembly wished to limit its request in such a manner, it could easily have chosen a clear formulation to that effect. The term "in accordance with" is broad by definition. ${ }^{34}$

To conclude, it can be stated that a court may use the technique of divisio in order to avoid addressing a sensitive or contested issue that has been raised by one of the parties. By basing the decision on a less problematic aspect of the claim or case at hand and by dealing with it exhaustively, the reasoning appears to be, and in fact usually is, a diligent execution of the judicial task with regard to the isolated issue. Even if commentators recognise that an important element of the substantive question raised has been left unanswered, it may thus be found more difficult to criticise the court for its avoiding an answer to the question, given that the judgement as such has been reasoned and delivered in accordance with recognised standards of the legal craft. The mere extensiveness and depth of the court's analysis of the other points creates the impression that the party's argument has received close scrutiny despite the decisive issue having been passed over by the court.

\section{Immutatio / Ignoratio elenchi, Fallacy of Irrelevant Conclusion}

\section{a) Rhetorical Characteristics}

Another type of avoidance is a reformulation of the question so that the court gives an answer that does not relate to the question as raised by the applicant. On a linguistic level, this strategic manoeuvre can be identified by the use of immutatio, i.e. a technique of detraction and adiection, which diminishes adverse points and brings in new aspects: 'Immutatio can alter the individuality of the whole.'35 Of course, immutatio cannot only be discussed

34 ICJ, Kosovo (n. 28), 479.

35 Lausberg, Orton and Anderson (n. 14), \462.4. 
in connection with elocutio, but also in regard to inventio and from an argumentative perspective it produces a fallacy as the court does present a conclusion that is irrelevant to the question raised (ignoratio elenchi).

\section{b) ECJ on Villeroy \& Boch v. EU-Commission}

As to the rhetorical technique of 'reformulating the question', an example can be found in the jurisprudence of the European Court of Justice (ECJ) on antitrust law in the Villeroy $\&$ Boch case. ${ }^{36}$

The ECJ is relevant when it comes to the analysis of avoiding judicial strategies since it is a transnational court which is pinched between strong political forces. While it is bestowed with the task to monitor and sustain the process of European integration, it is at the same time in charge with the supervision of the powers exerted by the institutions of the EU, including the Commission. The former prominently involves preliminary rulings under Article 267 of the Treaty of the Functioning of the European Union (TFEU), the latter is mainly a matter dealt with in actions for annulment under Article 263 TFEU against legal acts rendered by the European institutions. It is therefore upon the ECJ in its jurisprudence to carefully balance the political interest in safeguarding the legality of actions of the European institutions without undermining the authority of the EU vis-à-vis the member states, external actors and the participants on the internal market. ${ }^{37}$ As to the ambition to protect the authority of the European institutions, the Luxembourg courts are sometimes perceived as paying a certain amount of judicial deference towards the EU Commission in actions for annulment of the Commission's decisions relating to market participants in competition law issues. ${ }^{38}$ While this percep-

36 ECJ, Villeroy E Boch v. European Commission, judgement of 26 January 2017, case no. 625/13 P, ECLI:EU:C:2017:52. For the sake of disclosure, we inform that Stefan Thomas has counselled the applicant in this case.

37 On the 'political questions' doctrine in the jurisprudence of the ECJ: Odermatt (n. 9), 229-230.

38 A general stance of 'judicial deference' to the Commission's assessments appears to have been introduced in the Consten and Grundig-judgement, and then confirmed in the Remial Nutricia-decision, cf. Ian Forrester, 'Deference to Public Authority: A Judicial Equivalent of Cupressus Leylandii' in: Studienvereinigung Kartellrecht e. V. (ed.), Kartellrecht in Theorie und Praxis (München: Verlag C. H. Beck 2012), 184; Igor Nikolic, 'Full Judicial Review of Antitrust Cases after KME: A New Formula of Review?', European Competition Law Review 33 (2012), 583-588 (586). Statistics show an increasing restraint of the EU courts to annul Commission decisions and reduce fines, cf. Damian M. B. Gerard, 'Breaking the EU Antitrust Enforcement Deadlock: Re-empowering the Courts?’, E. L. Rev. 36 (2011), 457-479 (469). For example, a study shows that in 2012 and 2013 the Commission's overall success in merger and antitrust appeals in the European courts was 90 \% (2012) and 77 \% (2013), cf. Henry Vane, 'The House Always Wins', Global Competition Review 17 (2014), $5 \mathrm{ff}$. 
tion is mainly related to the standard of review of facts, ${ }^{39}$ and to the significant margin of discretion the judicature is considered to enjoy in some matters of substantive law ${ }^{40}$ and of procedural law, ${ }^{41}$ the example to be discussed in the following possibly indicates that the courts can also be found to employ rhetorical techniques to resolve legal intricacies in a given case.

In the Villeroy $\&$ Boch judgement the ECJ employed a line of argumentation to uphold a decision rendered by the General Court (GC) which had confirmed a fine decision by the Commission in the bathroom fixtures cartel. There, the EU-Commission had found Keramag and Villeroy E Boch to have committed an antitrust violation on the French market among other areas of the EU. As to the French market, though, the allegations were based solely on an ambiguous statement made by a leniency applicant. No further evidence corroborated the Commission's allegations. Both firms challenged the Commission's decision. In their actions for annulment before the GC, both

39 The EU courts grant the EU Commission a broad margin of discretion concerning complex economic or technical assessments, cf. Marco Bronckers and Anne Vallery, 'Fair and Effective Competition Policy in the EU: Which Role for Authorities and Which Role for the Courts After Menarini', European Competition Journal 8 (2012), 283-299 (290); Csongor I. Nagy, 'EU Competition Law’s Fair Trial Revolution: Much Ado About Nothing?', European Competition Law Review 37 (2016), 232-238. Moreover, the EU courts do not carry out a full de novo review, and they generally refuse to substitute their own assessment for the Commission's decision, cf. Peter D. Camesasca, 'Cartel Appeals to the Court of Justice: The Song of the Sirens?', Journal of European Competition Law \& Practice 4 (2013), 215-223 (216); Renato Nazzini, 'Judicial Review after KME: An Even Stronger Case for the Reform That Will Never Be', E. L. Rev. 40 (2015), 490-508 (494); Andrea Usai, 'How Switching Towards an Adversarial System Might Make Fairness and Efficiency Bedfellows in Cartels Enforcement', European Competition Law Review 35 (2014), 542-554 (547). While in the KME- and Chalkor-case the GC held that despite of the Commission's margin of appreciation in complex economic matters, the EU courts still have broad review powers, the EU courts do not consider themselves to be obliged to undertake a full review of Commission decisions.

40 The EU courts grant the Commission discretion regarding the setting of fines so long as these comply with the Commission's guidelines. The jurisprudence therefore often declines to interfere with the Commission's assessment. The GC generally limits itself to checking the Commission's decision's consistency with the Fining Guidelines (pursuant to Article 23(2)(a) of Regulation No. 1/2003, (2006/C 210/02), OJ C 210/2) without engaging in a significant proportionality review. Cf. Forrester (n. 38), 184; Gerard (n. 38), 458. Only in rare occasions has the GC reset the amount of the fine on the basis of its own appraisal deviating from the methodology used in the contested decision, cf. Nikolic (n. 38), 586.

41 Albeit Article 47 (2) CFR guaranteeing a fundamental right to a fair hearing corresponding to Article 6 ECHR, witnesses are practically never heard before the EU courts. The EU courts assume that they have a discretion regarding the hearing of witnesses, cf. Ulrich Soltész, 'Due Process and Judicial Review - Mixed Signals from Luxembourg in Cartel Cases', European Competition Law Review 33 (2012), 241-247 (245). While the GC has broad powers for gathering evidence, it has not recognised a right of the parties to produce or request evidence cf. Fernando Castillo de la Torre, 'Evidence, Proof and Judicial Review in Cartel Cases', World Competition 32 (2009), 505-578 (520). 
applicants put forward that the piece of evidence relied upon by the Commission for the French market was of insufficient probative value. As to Keramag, the GC agreed so that the decision was annulled with respect to France. However, in regard to Villeroy $\&$ Boch, the GC held the same piece of evidence to be sufficiently clear to find a cartel in France. The decision on Villeroy $\&$ Boch was upheld.

Thus, in an appeal before the ECJ, Villeroy $\&$ Boch raised the plea that the GC had breached the principle of in dubio pro reo (presumption of innocence). In acquitting Keramag for lack of evidence and upholding the fine on Villeroy $\&$ Boch, the GC had demonstrated that the sole piece of evidence, on which the allegations had been founded in both instances, was ambiguous. The probative value of a piece of evidence cannot be sufficient and insufficient at the same time. The legal question to be answered by the ECJ therefore was how a verdict of a court can reconcile with the in dubio pro reoprinciple if the court has exclusively relied on evidence, which the court itself has considered to be too brittle to hold liable another alleged perpetrator for the same infringement.

Albeit potentially dispositive to the outcome of the case, the ECJ rejected this ground of appeal without crafting an answer to the legal question on the in dubio pro reo-principle. The ECJ initially recapitulated the question including the in dubio pro reo-part. Its subsequent line of argumentation, however, led away from this question and never returned to it. Instead, the court reiterated a set of undisputed facts and general legal principles. ${ }^{42}$ When the ECJ finally appeared to recap the question in order to formulate a conclusion, parts of the initial question as raised by the applicant were omitted. ${ }^{43}$ While the applicant had asked whether the GC judgement reconciled with the in dubio reo-principle, the ECJ in para. 41 did not mention the in dubio pro reo-principle any more. Rather, the ECJ stated the plea to have been about both GC judgements being 'contradictory'. In rephrasing the question like that, the ECJ created the impression that the applicant's argument was confined to the mere fact that these two judgements deviated. However, that was not the ground of appeal as raised by the applicant. The ground of appeal was about the in dubio pro reo-principle.

42 In Villeroy $\&$ Boch (n. 36), paras 38-40, the ECJ rolls out undisputed legal principles concerning the scope of judicial review of the ECJ, and it recapitulates some of the facts of the case which had not been challenged at all before the ECJ. In para. 38, for example, the ECJ outlines extensively that 'an appeal lies on points of law only'. However, an infringement of the in dubio pro reo principle is a point of law, and the ECJ does not even argue to the contrary.

43 Villeroy E Boch (n. 36), para. 41. 
Henceforth, the ECJ only elaborated on the reshaped version of the ground of appeal. The court stated that the mere fact that two judgements deviate in some points did not call for an annulment. Eventually, the ECJ rejected the ground of appeal in para. 45 without returning to the potential infringement of the in dubio pro reo-principle as addressed by the applicant.

In conclusion, the ECJ judgement exemplifies all pertinent elements of a rhetorical strategy of immutatio. Rephrasing the question allows to relate the answer to a question that was reshaped by the court ('Is a deviation of two parallel judgements in itself a sufficient ground for an appeal?'). In answering this question, the court eschews an answer to the more intricate question as raised by the applicant ('Can it reconcile with the in dubio pro reo-principle if a court relies on a piece of evidence which the same court has found insufficient?').

\section{Constitutio translativa: Attributing Wrong Premises}

\section{a) Rhetorical Characteristics}

Another strategic manoeuvre to avoid a question is to plainly deny jurisdiction in a certain case. The court will then put forward that the whole question was raised under the incorrect premise that the court has responsibility or jurisdiction to decide. In classical rhetoric, denying competence of the court is one of the last possibilities for the defendant to avoid a verdict. A constitutio translativa, ${ }^{44}$ as it is called, is recommended in rhetorical literature for cases in which an acquittal would be highly unlikely if the court exerted its jurisdiction. The defendant might therefore only escape the sanction by denying jurisdiction. When courts apply such a rhetoric on their own, however, this precipitates serious implications. Such a strategy might be used by judges as a means of last resort in order to avoid decisions on the merits of a case that are potentially controversial. In its effects, the constitutio translativa is a particularly drastic form of judicial avoidance since it precludes any substantive pronouncements of the court on the case.

44 Cf. Cicero, De Inventione, I.6; Michael J. Hoppmann, Argumentative Verteidigung: Grundlegung zu einer modernen Statuslebre (Berlin: Buchverlag Weidner 2008). 


\section{b) ICJ in Marshall Islands}

In the 2016 dispute between the Marshall Islands and the United Kingdom (UK), ${ }^{45}$ the Marshall Islands had claimed that the UK had violated its obligations under the Non-Proliferation Treaty (NPT). Under that treaty of 1968 the then existing five nuclear powers had assumed the obligation to 'pursue negotiations in good faith on effective measures relating to cessation of the nuclear arms race at an early date and to nuclear disarmament, and on a treaty on general and complete disarmament under strict and effective international control'. ${ }^{46}$ In return, all other states had committed themselves to not acquire any nuclear weapons in the future. What the Marshall Islands did in this case was to point to the fact that most nuclear powers had neither reduced their nuclear arsenals over the course of the last 45 years nor launched new initiatives for a complete treaty-ban of nuclear weapons. Given that all five permanent Security Council members are nuclear powers with growing arsenals and an apparent disinclination to ban nuclear weapons altogether, a court ruling in favour of the Marshall Islands would have had dramatic consequences for the NPT-regime. It would have exposed that the deal struck in 1968 between the beatus possidendi and the nuclear 'have nots' had not been honoured by the nuclear powers. Such a decision could have destabilised the NPT-regime and could have led the Court into a serious political confrontation with the five permanent UN Security Council members. ${ }^{47}$ Unsurprisingly perhaps, the Court held right at the outset of the handling of this dispute, within its Preliminary Objections, that the case was inadmissible. In order to achieve a possibility to deny its own jurisdiction, the Court introduced a new criterion regarding the admissibility of a case. What was remarkable, though, was the fact that this new criterion had never been used or even mentioned in its previous case law. The ICJ in previous decisions had held

45 ICJ, Obligations concerning Negotiations relating to Cessation of the Nuclear Arms Race and to Nuclear Disarmament (Marshall Islands v. United Kingdom), judgement of 5 October 2016, ICJ Reports 2016, 833; on the Court avoiding a decision on the merits in this case more generally Antony T. Anghie, 'Politic, Cautious, and Meticulous: an Introduction to the Symposium on the Marshall Islands Case', AJIL Unbound 111 (2017), 62-67; Andrea Bianchi, 'Choice and (the Awareness of) Its Consequences: the ICJ's "Structural Bias" Strikes Again in the Marshall Islands Case', AJIL Unbound 111 (2017), 81-87; Surabhi Ranganathan, 'Nuclear Weapons and the Court', AJIL Unbound 111 (2017), 88-95; Nico Krisch 'Capitulation in The Hague: The Marshall Islands Cases', 2017, EJIL Talk!, <https://www.ejiltalk.org/> (last accessed 1 March 2018); Odermatt (n. 9), 231-232.

46 Treaty on the Non-Proliferation of Nuclear Weapons, 729 UN Treaty Series, 161, Article VI.

47 Cf. Ranganathan (n. 45); Krisch (n. 45). 
that in order for an action to be admissible the case had to be based on a 'dispute' that already existed at the time when the case was submitted to the Court. ${ }^{48}$ Given that this condition was fulfilled in the case at hand, the Court created a new 'subjective' criterion, according to which the respondent also needed to be 'aware' of the dispute, which in the view of the Court the UK had not been at that point in time:

"41. The evidence must show that the parties "hold clearly opposite views" with respect to the issue brought before the Court (see paragraph 37 above). As reflected in previous decisions of the Court in which the existence of a dispute was under consideration, a dispute exists when it is demonstrated, on the basis of the evidence, that the respondent was aware, or could not have been unaware, that its views were "positively opposed" by the applicant [...].'49

The introduction of the 'awareness'-criterion was not endorsed by all judges in this case. The bench was split (eight to eight), and it was only through the casting vote of the ICJ's President that the Court could eventually follow this approach in order to reject the case as inadmissible. ${ }^{50}$ It was critically remarked among the members of the bench that the reliance of the Court on this newly created criterion was unprecedented in its own jurisprudence. Judge Crawford in his dissent addressed the tenuous reasoning of the majority:

'6. While the term "awareness" has sometimes been used in other cases in deciding whether there was a dispute, it has never been stated as a legal requirement, only as a description of the factual situation [...].51

The dissenting opinion underpins the assumption that the introduction of the 'awareness'-criterion can be perceived as a strategical move by the court. By the creation of the new criterion the Court puts itself in a position from which it could argue that the entire legal issue was raised under the incorrect premise that the Court has jurisdiction. This allows the Court to formally decide the case by rejecting it as inadmissible without, however, touching upon the highly controversial substantive issues of nuclear disarmament as raised by the applicant. By strategically employing a constitutio translativa, the Court therefore avoids a constellation where it could possibly interfere

48 ICJ, Application of the International Convention on the Elimination of All Forms of Racial Discrimination (Georgia v. Russian Federation), judgement of 1 April 2011, ICJ Reports 2011, 84, para. 30; ICJ, Questions relating to the Obligation to Prosecute or Extradite (Belgium v. Senegal), judgement of 20 July 2012, ICJ Reports 2012, 444 ff., paras $53 \mathrm{ff}$.

49 Marshall Islands (n. 45), 850.

50 Marshall Islands (n. 45), $857 \mathrm{ff}$.

51 Marshall Islands (n. 45), 1095. 
with international politics in a way that could have precipitated a serious political confrontation.

The constitutio translativa is a particularly common strategy of judicial avoidance. Courts, by way of creating new admissibility-criteria or by making creative use of existing ones, can avoid to deal with the merits of the case entirely. Legal audiences, however, usually are particularly sceptical when courts in an often long awaited decision on a contested legal issue use a constitutio translativa to avoid the substantive issue in their reasoning. Courts arguably use this particularly drastic avoiding strategy only when the employment of other rhetorical avoidance strategies on the merits appears less convincing or even implausible.

\section{Simulatio: Creating, But Not Materialising New Principles}

\section{a) Rhetorical Characteristics}

While even the reformulation of a question still is at least loosely grounded on the question raised by a party, we also see strategic manoeuvrings where a court is adding new content to the discourse, but still ends up with avoidance. One phenomenon of such new content being added is related to the creation of new principles - normative claims of a general nature that have the quality to alter paradigms and the outcome of the relevant discourse, but do not materialise in the concrete case. This is an extreme form of dodging a question and evading an unfavourable issue.

There are several possible motives for such a strategic creation of 'new principles'. For one, the court could develop a new principle - that appeals to the plaintiff or a certain part of the audience - to win the support of either or both for the judgement at large. This motive may apply in constellations where particularly critical reactions to the judgement are expected. Even if the abstract principle is not (fully) applied to the concrete case, its creation may signal sensitivity to certain claims out of this critical audience and the relevant social context. Second, the court could create the principle as an argumentative tool for applications in future cases that may have specific facts. The second motive is related to the first motive to the extent that it may already offer some relief for the party losing today to know that there might be a chance of succeeding in the future. Third, the court may want to send a signal to the party (authority) that is challenged in the court. This signal may be that there is a certain standard of judicial control over this party (authority) that could hypothetically be activated in future cases ('display of torture 
instruments'). Thus, the signal may have an anticipatory effect and influence the current practices of the relevant party (authority) already in a direction sympathetic to the court - without a formal conviction in a judgement on the merits.

\section{b) US Supreme Court in Masterpiece Cakeshop v. Colorado Civil Rights Commission}

As an example of simulatio, heed shall be paid to the decision of the US Supreme Court in Masterpiece Cakeshop v. Colorado Civil Rights Commission. ${ }^{52}$ The case was about the owner of a bakery who refused to make a cake for the wedding of a gay couple citing his religious beliefs as a Christian which interfered, in his view, with such task. The Colorado Civil Rights Commission, however, found the refusal to be unlawful under the state's anti-discrimination law and issued orders for the bakery. Subsequent appeals within the state affirmed the Commission's decision. Eventually, the case was taken to the US Supreme Court.

As a matter of substantive law, the dispute brought up the question whether and to what extent First Amendment claims of free speech and free exercise of religion could amount to an exemption from the anti-discrimination laws in public accommodation. The case was perceived as having the potential to address fundamental issues on the conflict between religious freedom, free speech, and anti-discrimination laws. Academics expected general clarification on these issues. ${ }^{53}$ One commentator stated that the case had 'loomed as a blockbuster' for that matter. ${ }^{54}$

The court ordered a reversal of the decision of the Colorado Civil Rights Commission and also reversed the affirming judgement of the Colorado Court of Appeals. Justice Anthony Kennedy delivered the opinion of the court. The judgement was a 7-2 decision with Ruth Bader Ginsburg and Sonia Sotomayor dissenting.

From a rhetorical perspective, Kennedy's opinion can be conceived of as another emanation of a simulatio technique. Initially, Kennedy acknowledges the intricacies arising from the reconciliation of the protection of the rights

52 Masterpiece Cakeshop v. Colorado Civil Rights Commission, 584 U.S. (2018).

53 Kyle C. Velte, Why the Religious Right Can't Have Its (Straight Wedding) Cake and Eat It Too: Breaking the Preservation-through-Transformation Dynamic in Masterpiece Cakeshop v. Colorado Civil Rights Commission, Minnesota Journal of Law \& Inequality 36 (2018), 6794.

54 Garrett Epps, Justice Kennedy's Masterpiece Ruling, The Atlantic, 4 June 2018, available at $<$ https://www.theatlantic.com $>$ (last accessed 8 February 2019). 
and dignity of gay persons on the one hand with the rights under the First Amendment on the other. In the course of his opinion, Kennedy then places great emphasis on honing the first principle, i. e. the obligation of the state to protect the rights and dignity of gay people. He writes:

'Our society has come to the recognition that gay persons and gay couples cannot be treated as social outcasts or as inferior in dignity and worth. For that reason the laws and the Constitution can, and in some instances must, protect them in the exercise of their civil rights. The exercise of their freedom on terms equal to others must be given great weight and respect by the courts.' (at 9).

Despite recognising that people can also have religious and philosophical objections to gay marriage, Kennedy asserts that 'it is a general rule that such objections do not allow business owners and other actors in the economy and in society to deny protected persons equal access to goods and services under a neutral and generally applicable public accommodations law' (at 9). Several statements reiterate this stance. With respect to gay people, he holds that: 'The exercise of their freedom on terms equal to others must be given great weight and respect by the courts.' (at 9). Gay persons must not be subjected to 'indignities when they seek goods and services in an open market' (at 18).

What is remarkable is that, albeit having set the scene for reconciling these two principles, i. e. protection of gay people and First Amendment rights, the opinion does not resolve the issue. Instead, the opinion shifts its focus from here to the reasoning of the Colorado Civil Rights Commission. Kennedy finds that quotes from the file show the Commission had not considered the bakery owner's religious objections with the required neutrality (at 17). Kennedy finds indications of hostility of some members of the Commission towards the owner of the bakery (at 14). Also, Kennedy holds that the Commission has given 'disparate consideration' of the arguments in this case compared to similar cases (at 18). He therefore finds that the owner of the bakery had been deprived of a neutral decision-maker in his case, so that the decision had to be reversed.

From a rhetorical perspective, this line of argumentation is significant. Those elements of the opinion in which the duty of the state to protect the rights and dignity of gay persons are addressed do not materialise in any legal conclusion which is relevant for the outcome of the case. Kennedy bases his objections against the Commission's reasoning solely on some of their members' alleged biases against the bakery owner's religious beliefs. It is not dispositive to this outcome, however, if and to what extent the principle of protecting the rights and dignity of gay people, which Kennedy has honed in the first part of his opinion, could require consideration when exercising 
one's Frist Amendment rights. Remarkably, Ruth Bader Ginsburg in her dissenting opinion, being joined by Sonia Sotomayor, writes that there 'is much in the opinion with which I agree' (at 1). She refers to those statements by which Kennedy emphasises the principle of protecting the rights and the dignity of gay people. She concludes that Kennedy's statements made with respect to these principles pointed into another direction than that in which the court eventually decided (at 2).

Ginsburg's remarks highlight an inflection point in the line of argumentation which eventually indicates a rhetorical manoeuvre of simulatio. The vocal endorsement of the principle of respect towards the rights and dignity of gay people has the quality to alter paradigms and could have been decisive for the outcome of the dispute, yet switching to the other line of argumentation which focuses on the lack of objectivity of the Commission ensures that these principles will not materialise in the dispute.

This line of reasoning fits into the perception that a decision on the conflict between antidiscrimination laws and the First Amendment Rights could have precipitated serious disturbances in society and politics and would perhaps have provided instability to the legal process. ${ }^{55}$ Such impact was avoided, or at least mitigated, by Kennedy emphasising that the rights and dignity of gay people must be protected whilst eschewing a ruling on whether First Amendment rights can prevail in a particular case.

\section{Playing for Time / Reticentia}

\section{a) Rhetorical Characteristics}

Playing for time is a powerful strategy to avoid a question. On a linguistic level it means to fall into silence (reticentia). Intentional silence can be qualified as a linguistic device. It is traditionally considered as a strategy that is used 'based on a conflict between the content of the omitted utterance and an opposing force that rejects the content of the utterance'. ${ }^{56}$ Playing for time can become relevant where the speaker is confronted with an intricate question the answer to which could precipitate serious opposition or conflict. This can be the case where the answer would be considered provocative by

55 Velte (n. 53), 68; see also Michaela Hailbronner, 'All Same-Sex Marriage Is not the Same: Obergefell from a Comparative Perspective' in: Anna-Bettina Kaiser, Niels Petersen and Johannes Saurer (eds), The U.S. Supreme Court and Contemporary Constitutional Law: The Obama Era and Its Legacy, (Baden-Baden: Nomos / London: Routledge Publishers 2018), 133-147 (144-145).

56 Lausberg, Orton and Anderson (n. 14), $\ 888$. 
large parts of the public opinion or where religious beliefs could be affected. Against this background, reticentia is a rhetorical strategy which can be effective when it comes to the protection of the reputation of a speaker in a case that poses ethical predicaments (genus turpe).

\section{b) German Federal Constitutional Court on Head Scarf Ban}

The technique of reticentia is underlying the judgement of the German Federal Constitutional Court (FCC) in the case known as Head Scarf I of 2003. ${ }^{57}$ The case was decided upon the constitutional complaint of Fereshda Ludin, a female school teacher by training. Ms. Ludin was born in Afghanistan in 1972, but had lived in Germany since 1987 and had become a German citizen since. Ms. Ludin is of Muslim faith. After graduation she applied for a position as school teacher in a state school in Baden-Württemberg. She insisted on wearing the head scarf in the class room. As a consequence, the competent state school authority in the Land Baden-Württemberg refused the appointment of Ms. Ludin, which she challenged in the courts as violation of her fundamental right to religious freedom.

Doctrinally, the case presented a fundamental challenge to German constitutional law. There was a multi-dimensional constitutional law conflict at stake that involved not only the fundamental right to religious freedom of Ms. Ludin, but also the negative right to religious freedom of the pupils, the rights of parents, the constitutional principle of religious neutrality of the state, and the constitutional duty of the state to organise the system of school education.

Moreover, the case raised the question to what extent the constitutional doctrines on religious freedom had to be adjusted to the changing role of religion in German society. Traditionally, the FCC held a very broad interpretation of religious freedom extending to all religiously motivated activities of daily life. The doctrine originates, however, from the 1960 s - when $90 \%$ of the German population belonged to one of the Christian confessions, which were undisputedly powerful societal forces. ${ }^{58}$ In contrast, the German society of the 21 st Century is marked by religious pluralism with a multitude of additional religions being present, among which the Muslim faith is the quantitatively by far most important non-Christian religion.

\footnotetext{
57 Bundesverfassungsgericht, judgement of 24 September 2003, BVerfGE 108, 282 - Kopftuchverbot $I$.

58 Bundesverfassungsgericht, order of 16 October 1968, BVerfGE 24, 236 - Lumpensamm-
} ler. 
The challenge of changing attitudes towards religion in the sphere of public schools, though, was not entirely new to the FCC. Only a few years earlier, in 1995, the FCC had decided the Crucifix case, in which atheist parents and their children had challenged a Bavarian statute allowing crucifixes in classrooms. ${ }^{59}$ Then, the FCC had taken on a decidedly activist role and quashed the state statute in a balancing act as a violation of the negative religious freedom of the parents. However, the Crucifixjudgement sparked a massive public outcry of opponents including several important politicians, especially from the governing party in Bavaria, the Christlich Soziale Union (CSU). ${ }^{60}$ The acceptance of the judgement not only among conservative elites was seriously in question, maybe more than any judgement at any point earlier in the history of the FCC. In the crucifix-context, the problem of the countermajoritarian difficulty - that is usually not much of an issue in Germany - all of a sudden was very present.

The approach of the FCC in Head Scarf I stands in stark contrast to the Crucifix-judgement. In Head Scarf I, the FCC does not engage in substance with the constitutional rights conflict at stake in a very deep way at all. Rather, the court avoids a substantial decision. As an explanation, the FCC invokes an institutional argument and holds that it was for the (democratically elected) (state) legislature to decide. As a result, Ms. Ludin won the actual 2003 case, for a fitting statute on a head scarf ban was missing. However, the FCC had at least implicitly acknowledged the right of the (state) legislature for the statutory enactment of a head scarf ban, so that the future employment of Ms. Ludin in the German school system was far from guaranteed, should she insist on wearing the scarf.

With the referral of the substantial decision to the (state) legislature, the FCC avoided the substantial question at stake by playing for time (reticentia). As in the definition of reticentia in rhetoric scholarship, the argumentative playing for time could well be explained by a fear for public opposition to the judgement and the struggle not to endanger public reputation (as the immediate example of public opposition against the Crucifix-judgement in 1995 and the delegitimising dimension presumably still was a very present experience to the judges).

59 Bundesverfassungsgericht, order of 16 May 1995, BVerfGE 93, 1 - Kruzifix.

60 For the account of then-Judge at the Federal Constitutional Court Dieter Grimm of the events see Dieter Grimm, 'Ich bin ein Freund der Verfassung' Wissenschaftsbiographisches Interview von Oliver Lepsius, Christian Waldhoff und Matthias Roßbach mit Dieter Grimm (Tübingen: Mohr Siebeck 2017), $146 \mathrm{ff}$. 
The immediate academic reviews on Head Scarf I were very clear about the avoiding character. 'The FCC denied to clarify what the law is' ${ }^{61}$ or 'Karlsrube locuta, causa non finita' 62 some commentators said.

'Playing for time' means - as a rhetorical figure - that the speaker postpones the answer to avoid being attacked in the present context. However, the question might arise again further down the road so that reticentia will not necessarily terminate a conflict. That can also be seen in the legal head scarf debate. After the state legislators in various German states had fulfilled the legislative duty proposed in Head Scarf I and had enacted new statutes on head scarf bans, these new provisions were again challenged in court. The substantial question returned to the FCC. In 2013, two female school teachers with Turkish origins challenged one of the newly enacted head scarf bans with a constitutional complaint to the FCC. This time, the FCC - sitting in a different composition of justices ${ }^{63}$ - did not avoid, but argued and decided on the merits - in favour of the applicants. ${ }^{64}$ The Head Scarf II-judgement of 2015 immediately raised significant critique in the public and in legal scholarship which cannot be discussed in detail here. ${ }^{65}$ It can be said, however, that in retrospect it makes the avoiding character of Head Scarf I even clearer. To conclude, the line of argument of the FCC in the first Head scarf case is a telling example for the use of reticentia.

\section{Conclusion}

The aim of this paper was to add a new intra- and interdisciplinary perspective to the immense literature on judicial decision-making. We have focused primarily on identifying five rhetorical avoidance strategies in the judicial reasoning of four courts, two domestic, one regional and one international. The analysed judgements can only provide exemplary evidence for the existence of judicial avoidance strategies. We assume, however, that the employment of avoidance strategies, as found in this non-comprehensive list of rhetorical manoeuvres, could potentially be identified in the practice of all

61 Karl-Hermann Kästner, 'Verweigerung einer verfassungsrichterlichen Klärung der Rechtslage', JZ 58 (2003), 1178.

62 Jörn Ipsen, 'Karlsruhe locuta, causa non finita - Das BVerfG im so genannten "Kopftuch-Streit"', NVwZ 22 (2003), 1210-1213.

63 According to the rules of internal allocation of cases in Head Scarf I the case was assigned to the 2nd Senate, in Head Scarf II to the 1st Senate of the FCC.

64 BVerfG, judgement of 27 January 2015, BVerfGE 138, 296.

65 See Mathias Hong, 'Two Tales of Two Courts: zum Kopftuch-Beschluss und dem "horror pleni"', (Verfassungsblog, 2015) at <http://www.verfassungsblog.de> (last accessed 22 June 2021). 
courts and tribunals and in all branches of the law. Through the help of rhetorical science and linguistic literature it was possible to analyse in more depth how judicial avoidance works and to describe recurring patterns of avoidance. By way of conclusion, three general questions need to be addressed: Why is judicial avoidance a common and relatively accepted practice of courts and tribunals? What are structural reasons for judicial strategies of avoidance? And does judicial avoidance nonetheless bear inherent and generalisable risks for the judicial function?

As to the question of acceptance, insights from linguistics again help us to understand why judicial avoidance can be a successful communicative strategy for a court. In interpersonal communication, dodging a question and evading unfavourable arguments generally is a highly effective communicative strategy as Todd Rogers showed in his study 'The Artful Dodger: Answering the Wrong question in the Right Way':

'We might expect that when people dodge a question by answering a different question, listeners would both notice the dodge and rate the dodger negatively. To the contrary, we found that listeners engaged in their default goal of socially evaluating speakers did not rate speakers poorly when they dodged a question by answering a similar question - a lack of disapproval that went hand-in-hand with their failure to detect that the speaker had dodged. We proposed, and offered evidence in support of, two key factors in dodge detection: the attentional goal of the listener, and the similarity of the answer to the actual question. ${ }^{66}$

Evading an argument is often unrecognised by the audience since rhetorical research indicates that while the audience expects the challenged party to render an answer, it is of lesser relevance for the audience whether the answer fully reflects the question which was asked. The same is true for whether the answer is correct or wrong. What is important for the audience to perceive the challenged speaker as a powerful orator is that the orator reacts. It is of lesser importance, though, for the impression of a powerful reply whether the answer is thorough or whether the speaker merely dodges the question. It was Aristotle who already had the intuition that it is much easier to convince an audience if any reason is given than if no reason is given at all. ${ }^{67}$

As to the second question of structural and generalisable reasons for judicial avoidance, we can infer from the cases analysed above that in all instances the political or economic stakes were high, and any non-avoiding judgements could potentially have led to serious confrontation with strong

66 Todd Rogers, 'The Artful Dodger: Answering the Wrong Question in the Right Way', Journal of Experimental Psychology 17 (2011), 139-147 (145).

67 Cf. Aristotle, Topics, $175 \mathrm{a}-\mathrm{b}$. 
political actors or to an external or internal institutional crisis. A structural reason for judicial avoidance thus can be strong institutional conflicts and a high degree of political pressure from powerful actors on the court. We can thus assume that a high frequency of avoiding legal conclusions in a particular field of law indicates that the respective courts find themselves in a conflictual- and high-pressure situation. ${ }^{68}$ We can also infer that lower courts are possibly less likely to use avoiding strategies because the pressure is of a lesser degree if a court knows that appeal structures will lead to further and ultimately binding decisions on the case. Mitigation of a potential or developing institutional crisis can be an important motive for judicial avoidance, which can be demonstrated in the Marshall Islands ICJ-case. But courts can also be inclined to use avoiding strategies to mitigate an internal conflict between the judges in an attempt to find a common position acceptable to all or at least a considerable majority of judges.

The third question to address here concerns possible risks for the judicial function. Our findings might pave ground for further investigations into the reasons behind the phenomenon of judicial avoidance. An awareness for strategies of judicial avoidance can help to identify structural conflicts of interests that have arisen in a given case. Such conflicts might have thrust the court into a difficult situation, in which a strategy of judicial avoidance was considered the best option available. A refined scholarly awareness for these argumentative manoeuvrings can contribute to identifying and understanding such conflicts. While striving to increase the awareness for strategies of judicial avoidance, we would be misunderstood if our findings were interpreted as legal or ethical criticism of this phenomenon. By describing the phenomenon in judicial reasoning, we want to contribute to its scholarly understanding. In fact, we still doubt if it is expedient to classify judicial avoidance as per se good or bad. Rather, avoiding strategies might serve illicit political opportunism in one case, while legitimately paying tribute to societal or institutional conflicts and crisis-situations in another. Judicial avoidance is therefore a highly ambivalent phenomenon.

A final observation relates to generalisable risks for the judicial function that come with the use of avoiding strategies. Judicial avoidance may be necessary in certain instances to mitigate conflicts and to avoid a dawning crisis, yet it also always means a partial denial of the central function of the court, which is to decide in a disputed legal issue brought before it. By doing so, the court leaves a particular legal question unanswered. The then inevitably persisting legal insecurity might have positive effects outside the

68 More generally on 'resilience strategies': Madsen, Cebulak and Wiebusch (n. 9), Section 3.2. 
legal system or short-term advantages for the judiciary. From an internal perspective, however, it can be an unsatisfactory solution. A court often using avoidance strategies thus ultimately bears the risk of promoting its own institutional irrelevance. To deny its role as a functional centre of the legal system that clarifies disputed substantive legal issues through exercising the full authority given to it by the legal system may damage the reputation of a court. A court might, at least in the long run, be conceived of by the public and by potential parties as an actor that, whenever the stakes are high, will give in to political opportunism instead of providing the answers to the legal questions raised before it. Then, why bother asking in the first place? 